\title{
SUSTAINABLE INITIATIVES IN MARGINAL RURAL AREAS OF SERBIA: A CASE STUDY OF DIMITROVGRAD MUNICIPALITY
}

\begin{abstract}
Juan-Pablo Rodriguez ${ }^{1}$
${ }^{1}$ IMRD, Humboldt University of Berlin, Faculty of Agriculture and Horticulture, rocallej@cms.hu-berlin.de

Abstract: This paper is based on a 2009 case study research on the role and impacts of rural initiatives in Dimitrovgrad, South-eastern Serbia region. This area is of interest, because of local efforts to conserve autochthonous livestock breeds, and the work of smallholders and independent professionals involved farming and rural tourism activities. The research used participant visits to initiative places, drawing on farm visits, meetings with stakeholders and analysis of secondary information. The study highlights that local organizations are running without link to initiatives. Although, Serbia country has well structured rural developments programs, those still are harmonising. Thus, through Actor-Network approach is suggested which turn around a farm manager. This may represent to all stakeholders with initiatives (on-farm and non-farm). Besides, local food products issues from initiatives may reconnect providers and consumers, revaluing local food products. However, is necessary the institutional and organizational involvement to encourage the initiatives. Furthermore, to promote touristic places, by an integrated rural tourism approach it may involve all stakeholders to promote local products and issues from initiatives. Indirectly it may create local employs.
\end{abstract}

Key words: rural initiatives, local agrobiodiversity, sustainability, South-Eastern Serbia

\section{Introduction}

European countries have improved rural infrastructures and supported the abilities of villagers in remote and marginal rural areas, through adequate development policies. In countries with few smallholding areas, other alternatives to improve these situations have been developed over time. Initiatives become sustainable activities and possible door for developing remote area, using animal and plant local genetic resources and innovation activities (Mühlinghaus and Wälty, 2001; Milone, 2009). Countries in transition are starting from the bottom, as it is the case of Serbia, which remained with the harmonization of their development policies addressed to improve slightly the vulnerable and remote rural areas (Bogdanov, 2006, 2007).

However, endogenous development takes into account a sustainable way of development by improving and creating rural innovations based on local resources (Kucerova, 2002; Remmers, 1996, 2006). Main actors involve local population and use of natural resources, promotion of rural areas and traditional activities through rural tourism (agro-tourism and eco-tourism). Employing local livestock in agriculture often valorises the territory and maintain the landscapes, meanwhile provides sustainability and liveability of smallholders in remote areas, including the system of an ecological, economic and social viewpoint, as well as rural villages have bred rare farm animals (Anderson, 2003; Köhler-Rollefson, 2007). Hence, in Serbia; several projects started for enhancing sustainability of smallholders and improve rural improve rural household welfare in mountainous areas, carrying out projects focused on recovering and revalorizing autochthonous livestock breeds and rebuilding places to develop rural tourism (Marczin et al., 2007; Stojanovic, 2008; Saxena \& Ilbery, 2008).

Although, rural development policies in Serbia have some constraints to support initiatives; local stakeholders and projects have started developing initiatives in South-eastern Serbia Region. Those set up around local resources. It arouses the attention in make out how local actors and external agents achieve agrobiodiversity and rural tourism projects. However, forms of local stakeholders' participation and other means have not been considered. This paper will focus on the nature on initiatives and rural tourism as means to develop and become successful maintenance of rural life style. The objectives of this paper are twofold; to note how do rural initiatives contribute to preserving local agrobiodiversity in marginal villages; second, to consider how local entrepreneurs may be sustainable organized. Next section of the paper outlines some theoretical frameworks which help to understand the background of rural initiatives in Southeastern Serbia. The results and discussions are covered by fourth section where are presented by a framework upon initiatives and development relations, and also an ActorNetwork approach surrounding initiatives is proposed. Finally, the paper ends with conclusions in the fifth section.

\section{Rurality and initiatives in South-eastern Serbia}

Serbia's rural areas are featured of traditional farming, and $55 \%$ population live in rural area. Often, there is a low and uncertain governmental support and a low productivity 
comprised by smallholder (3.5 ha). Hence, rural areas were considered as a problem and not as a resource. Moreover, former policies focused to support larger farmers and improving agricultural infrastructures; while that, smallholders had lacking technical and financial support. Additional, other problems have been the reversible migration from villages to cities. Therefore, economic structure in Serbia still depends on the primary sector and exploitation of natural resources. Chiefly, local projects are supported by local and external agencies through development projects (Bogdanov, 2008; S.O.R.S, 2008).

Rural initiatives are no registered as initiatives and/or activities in Serbian statistics accounts. Nevertheless, innovative activities exist according to a pilot survey (INOV), a study that compiled and drew most intensive innovation trend in organization of enterprises $(57.34 \%$ enterprises), and marketing sector showed slowest (28.81\% enterprises). Innovation of products/services and processes are almost the same $47.09 \%$ and 46.81 respectively. Over 100 totals of enterprises, solely comprises $7.2 \%$ of enterprises in agriculture, mining and quarrying sector exist (OSRS, 2008b).

Furthermore, former policies improved SMEs through establishing of producers associations and improvement of infrastructures. During the 1970s period the rural life had several changes, centralizing the development in cities and towns. It has modified completely the traditional style of rural areas. Despite de fact that rural development policies were established and led to support marginal and poorly rural areas, they were not adequate. Serbia has designed strategic policies to reduce main problems related to rural areas such as poverty, infrastructural means and business initiatives (Bogdanov; Djordjevic-Milosevic, 2008). Nevertheless, it is still harmonising between local stakeholders from different sectors.

\subsection{Initiatives in Dimitrovgrad marginal rural areas}

Rural households in Serbia South-eastern region are considered vulnerable and make up $25 \%$ of the rural poverty, mainly due to geographic location, social isolation, lack of access to communication and services (Ersado, 2006; Bogdanov; Djordjevic-Milosevic, 2008). In Dimitrovgrad, few years ago local projects are carrying out to develop and improve rural infrastructures and offer places for rural tourism activities. Moreover, rural initiatives entail on-farm activities (conserving indigenous farm animals) and nonfarm activities (rebuilding, renovating old housing, and rural tourism). Official documents and the socio-economic statistics still describe the territory of Dimitrovgrad as rural marginal area. A "rural marginal area" is defined to areas with less population than 100 inhabitants, regional intense depopulation process, higher ageing level, lack of infrastructures, and higher unemployment rate. (OECD, 1994; SORS, 2008a). During sixties, the villages were characterized by sheep breeding and traditional home-made sheep cheese. In spite of these negative trends, the countryside still preserves high and wealthy agro-biodiversity, local heritage and local traditions.

\subsection{Rural Development, integrated territorial agri-food approach and sustainable rural tourism}

Rural development terms are seen as implementation of political, economic and social project lead for a collective vision and future of rural regions. It involves the creation of new products, services and development of new markets. Seeing a new resurgence of interest in 'more natural' or 'more local' issue, particularly from territory, it is based on local food product. This implies a management of local resources beneath sustainable advantage patterns, and also takes economic aspects into account. It appears redefined as a model of identities, strategies, practices, interrelations and networks. (Marsden et al., 2000; van der Ploeg et al., 2000; Yves, 2005).

Sustainable rural development, suggest the need to regard the prevailing (and potentially new) condition which can be taken into emerging, social-scientific and political-economic relationships (Marsden, 2006; Sonino et al., 2008; Tovey et al., 2009). It conveys a conceptualization of social nature and rural development abroad some obstacles as the social construction of feature and the assumption of natural trend. Regarding upon last standpoint it suggest the ANT (Actor-Network-Theory approach) which includes interrelations between humannature interactions (Callon, 1999; Murdoch, 2000).

Concerning exogenous and endogenous processes Murdoch's (2000) draws upon networks and based on rural development issue; he claims two network models. i) Vertical networks that emerge linked to rural areas into agro-food sector and ANT. ii) Horizontal network which denote forms linked to rural spaces and non agricultural processes of economic change; it aim to integrate rural areas into the national and international economy.

Using local resources as means to enhance environmental sustainability of marginal areas, there is an approach on revaluing foods. Particularly, by taking local food products from rural territories linked to networks. Wiskerke (2009) suggests the place as a resource to promote integrated territorial agrofood. This focus addresses on the multitude of social, economic and ecologic problems. Besides, he also argues ways of organization through Short Food Supply Chains. This means a reconnection consumers and local food producers.

Keeping alternatives of progress for marginal areas, tourism development appears which integrates sustainable local actors, formal and informal networks. Integrated rural tourism encourages environmental, economic, and sociocultural sustainability in tourism, as well as encourages local people (Cawley \& Gillmor, 2008; Saxena \& Ilbery, 2010).

\section{Material and methods}

This study is based upon three initiatives, which achieve in Dimitrovgrad municipality. Case studies were hereby chosen as a research method, because these can to address 
the research question in a contemporary situation where there is no or very little control on the behavioural events (Ying, 2003). The fieldwork has been led upon summer 2009 in northern and southern villages of Dimitrovgrad Municipality (Gornji Krivodol, Smilovci, Prtopopinci and Zvonce). The case study compiles two methodology follows by a) visits done to the farm activities involved in rural on-farm and nonfarm initiatives, b) participant observations and informal meetings with stakeholders (interviews). In addition, walk around initiative places were realised, as well as a deep analysis of secondary information was done. Further, a framework is developed upon different relations set up on rural initiatives. Throughout, actor-network approach as a strategy of stakeholder association and likely dynamics is proposed as well. The main aim of the case study research was to catch on the dynamics of specific initiatives. Next, the cases also aimed to strengthen and deepen the understanding of themes regarding local resources and products developed by entrepreneurs. Hence, following section outlines the situation of three cases, which are part of rural initiatives.

\subsection{Farm Company in Gornji Krivodol and Smilovci Villages}

Smallholders and independent stakeholders of Dimitrovgrad countryside become the main actors of the rural initiatives in 2002. At the beginning a local NGO promoted the preserving of local animal breeds merely as a disinterest act for keeping Serbian traditional heritage in agriculture without a marketable purpose. This local NGO and Serbian Ministry of Agriculture (MAWFM) started first. Animals belonging to Balkan livestock breeds (donkeys, cattle, goat and sheep) have been identified by an agrobiodiversity conservation group.

To become sustainable, the agrobiodiversity conservation project, it is invested by two Belgrade private investors since 2008, who were interested in small farm breeding of threatened local animal breeds in a traditional way. After meetings with farmers from the local NGO in Dimitrovgrad, the investors decided to buy two middle sized farms in Smilovci and Gornji Krivodol villages (Stara Planina Mountain area - northern of Dimitrovgrad).

The local NGO activists and their partners from other municipalities of Dimitrovgrad, Pirot, Babusnica, Trgoviste, Bosilegrad and Bujanovac discovered many animals planned to be sold for slaughtering. However, the foreign investors acquired these animals and they were transported in farms in Gornji Krivodol and Smilovci villages. Nowadays, this project supported by investors on conserving local breeds is considered the most important initiative in Dimitrovgrad countryside as well as in Central Serbia in the field of agrobiodiversity conservation.

\subsection{Farm in Prtopopinci Village}

The initiative started in 2003, and had since beginning external cooperation combined with local projects, now remains by own funds. Currently it follows with the same perspectives as the conserving of autochthonous livestock breeds; particularly the local sheep, Alpino and Balkan goat breeds.

Moreover, one of the assets and products that are offered by this farm comprise the home-made cheeses. Nowadays, they are produced using artisanal techniques (e.g. cheeses of goat and sheep milk). Every year the owner takes participation in local and international events related on Balkan animal breeds. And also, the owner is a specialist in "traditional home-made cheese" and musician, attending in these events he was awarded and recognized due to his participation and the quality of his products.

Activities and services offered by this farm comprise the possibility to stay and to know the traditional South-East farming and rural life style. Furthermore, traditional music is performed by the owner of this farm as well as local heritage is represented through rare breeds. Local infrastructure is not adequate and still uses old housing like farmyard. However, while local products are made by traditional techniques and no certified organic production based on local breeds is elaborated in small scale.

\subsection{SPA Hostel in Zvonce Village}

SPA Hostel activity started with own funds and initiative, in order to produce additional income. It display to the people in Dimitrovgrad that is able make a livelihood out of rural tourism and produce local products promoting local potentialities and resources (landscape, river and preserved nature areas). Before, to start, the owner worked in Bosnia and Herzegovina. Thus, the initiative became after his experience with tourism activities in that country. Therefore, he decided begin with own means to renovate and rebuild his house combining with local features.

Since Dimitrovgrad is a border town between Serbia and Bulgaria, it presents manifold opportunities and possibilities for visitors and voyagers. Moreover, the owner is a teacher of a High School in Dimitrovgrad town. He is engaged recovering traditional and local heritage knowledge visiting other villages. Researches on ancient history and cultural heritage of Dimitrovgrad are done for him and are spelled in books. Throughout, working in the classroom he knows on the affection of students.

This initiative embarked on focusing upon local resources around Greben Mountain through hiking and staying in the SPA Hostel. Despite, the existence of alternatives to promote rural areas through tourism initiatives in Serbia, nonetheless, it needs procedures in order to get support and still are in process of harmonising with local actors.

\section{Results and Discussions}

\subsection{Organizations involved on rural initiatives in Dimitrovgrad}

There are a number of government, non-governmental organization and academic institutions supporting to 
initiatives involved through local development project. Their services included advisory and financial. Besides, some of these organizations are assisting in rural development projects in Dimitrovgrad. These are shown in table 1 and figure 1.

Table 1. Organizations involved through support to initiatives since beginning and nowadays in Dimitrovgrad marginal villages'

\begin{tabular}{|c|c|c|c|}
\hline $\begin{array}{l}\text { Name of } \\
\text { Organization }\end{array}$ & Status & Location & Main roles \\
\hline MAWMF & Public & \begin{tabular}{l|} 
Belgrade, \\
Dimitrovgrad
\end{tabular} & $\begin{array}{l}\text { Engaged since } 2002 \text { through } \\
\text { REC project. } \\
\text { Preservation local farm } \\
\text { animal breeds. }\end{array}$ \\
\hline SIDA & Private & Sweden & Financial and technical support. \\
\hline $\begin{array}{l}\text { Academics } \\
\text { and } \\
\text { Universities }\end{array}$ & $\begin{array}{l}\text { Public } \\
\text { Research }\end{array}$ & \begin{tabular}{l|} 
Nish \\
Belgrade \\
Dimitrovgrad
\end{tabular} & Drafting local strategies. \\
\hline $\begin{array}{l}\text { Municipality of } \\
\text { Dimitrovgrad }\end{array}$ & Public & Dimitrovgrad & $\begin{array}{l}\text { Supporting and coordinating } \\
\text { the improvement of local } \\
\text { infrastructures. }\end{array}$ \\
\hline Local NGO & Private & Dimitrovgrad & $\begin{array}{l}\text { Monitoring and establishing } \\
\text { of local agrobiodiversity. } \\
\text { Rural Development projects, } \\
\text { agriculture and organic } \\
\text { farming. }\end{array}$ \\
\hline $\begin{array}{l}\text { SAVE } \\
\text { Foundation }\end{array}$ & Private & Belgium & $\begin{array}{l}\text { Technical cooperation. } \\
\text { Advices on conserving } \\
\text { indigenous plant and animal } \\
\text { breeds. }\end{array}$ \\
\hline
\end{tabular}

Source: Own table.

The Ministry of Agriculture, Water Management and Forestry (MAWMF), is engaged since 2002 with REC Project on preserving local animal diversity around the Stara Planina Mountain Area. Through the Department of Genetic Resources, this sector focus on a strategy of conservation taking more cares upon sustainability of on-farm autochthonous livestock breeds. In addition, is engaged in provide technical advices to rural areas on farming, and animal breeding.

SIDA (Swedish International Development Authority) has been supporting through the project Reka Mleka, encouraging to dairy sector and improvement farmer skills

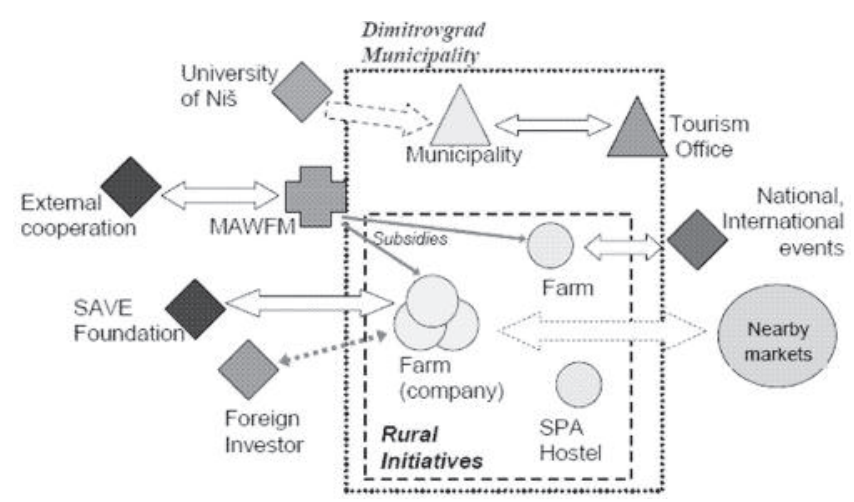

Figure 1. Organizations involved through rural initiatives in marginal villages of Dimitrovgrad Municipality (Source: Own Figure) by technical assistance. Principal aims of SIDA were financial support addressed to local development projects.

Academics and universities are also player in the local development and design of strategies to develop Dimitrovgrad. Often professors from Nish University are invited to City Hall in Dimitrovgrad town for drawing the development strategy. Regularly, every year the City Hall organizes meetings, further local stakeholders are invited.

The municipality of Dimitrovgrad is involved through local support and coordinating the improvement of local infrastructures in the town, and rural development projects. Some members of municipality council are starting with rural initiatives. The municipality coordinates between local actors and organizations.

The local NGO is engaged since 2002, beginning with the establishment of Agrobiodiversity project and monitoring of autochthonous animal breeds. This NGO has participated actively in projects of Rural Development, Agriculture and Organic Farming through advices to smallholders in villages carried out in Dimitrovgrad.

SAVE Foundation (Safeguard for Agricultural Varieties in Europe), this organization coordinates with BIOVERSITY in activities focused in conserving indigenous livestock breeds and plants distributed in Europe. Their aim is provide assistance and technical advices on native plant and animal preservation and avoid the disappearing local agrobiodiversity.

\subsection{Local projects encouraging development in marginal rural areas and partly supporting initiatives}

Rural development projects involved strengthening of smallholder skills on cattle management, rural tourism development, recovering autochthonous livestock breeds, local and traditional heritage. At the moment, local projects achieve supporting initiatives involved to local agrobiodiversity conservation partly coordinating with MAWMF (Table 2).

Table 2. Projects achieved and/or going in rural areas of Dimitrovgrad municipality around initiatives

\begin{tabular}{|l|l|l|}
\hline $\begin{array}{l}\text { Name of } \\
\text { Project }\end{array}$ & Location & Date of Execution \\
\hline $\begin{array}{l}\text { West Stara } \\
\text { Planina } \\
\text { Project }\end{array}$ & $\begin{array}{l}\text { Pirot District, Dimitrovgrad } \\
\text { municipality }\end{array}$ & $\begin{array}{l}\text { Was designed through two } \\
\text { Serbian and Bulgarian border } 2000-2006 \text { (first) and } \\
\text { municipalities surrounding } \\
2006-\text { at present (the project } \\
\text { is called Euro Region Project) }\end{array}$ \\
\hline $\begin{array}{l}\text { Reka } \\
\text { Mleka }\end{array}$ & $\begin{array}{l}20 \text { municipalities (Central } \\
\text { and Southern of Serbia) }\end{array}$ & $\begin{array}{l}2003-2006 \\
2006-2008\end{array}$ \\
\hline $\begin{array}{l}\text { IACP } \\
\text { Project }\end{array}$ & $\begin{array}{l}\text { Stara Planina Mountain } \\
\text { Area }\end{array}$ & $\begin{array}{l}\text { In execution } \\
\text { Project financed by REC. }\end{array}$ \\
\hline
\end{tabular}

Source: Own table.

West Stara Planina project was created in a stable partnership and institutions to support transboundary cooperation in the development of the region and empower 
local stakeholders and improve their welfare through supporting local tourism and agriculture initiatives. 11 pilot municipalities in the region were taken into account. This project was designed for two phases. Firstly, was carried out in 2000 and 2006. A second phase started and is more focused like Euroregion project involving Serbian and Bulgarian municipalities around Stara Planina Mountain area.

Reka Mleka project has been a project supported by SIDA. The main aim was encouraging to dairy sector and improvement of farmer skills by technical assistance. The project was led in two phases 2003-2006 and 2006-2008. Hence, 20 municipalities in Serbia were taken into account, further; improve abilities and strength technical knowledge to national and regional level was done.

IACP, current project is carried out through development of rural tourism in the Stara Planina Mountain area (through rural and conventional tourism) especially winter tourism. This project is financed by REC (Regional Environmental Centre). Besides, its role is support to initiatives around the area, as well as rebuilding rural tourism infrastructures (old housing restoration, etc.).

\subsection{Actors'-Network development surrounding initiatives}

Rural initiatives presented in this paper as cases make up role on endogenous development, actually focuses on-farm activities and non-farm activities. Over last years, projects for improving steadily rural household welfare in Pirot District have been carried out, particularly in municipalities around the Stara Planina Mountain area. What is more, agricultural initiatives are strengthening social networks by smallholder farms through innovative activities (i.e. networks created in local fairs, sharing of local knowledge).

The particular Farm (company project, Figure 1) sustained by private investor, local projects and technological assistance from an international network; still is better organising to reach local and organic animal products to the nearest markets. Particularly, this economical support is led for agrobiodiversity activities and rural tourism. Besides, the initiatives in Smilovci and Gornji Krivodol (company project) want to reach the local products to nearest local markets through strong alliances with specific retailers of typical products. Due to this short background, they tried to find strategically alliances and get more contacts, particularly promoting products in restaurants, and special markets based on products indigenous livestock breeds. At the moment, the farm company started to promote their products through short food exhibition in restaurants of Belgrade.

The initiative in Prtopopinci has demonstrated that participating in local fairs can to promote their local products and build networks. Indeed, the entrepreneur of SPA hostel believes, that may develop more tourism infrastructures, and so, attract more visitors. This would provide alternatives source of incomes and foster to young entrepreneurs take more interest in local means and products.
This scenario illustrate that, local organizations i.e. Tourism office, Local government (i.e. municipality) and external agents (University of Niš) are achieving activities without links over initiatives (Figure 1). Instead, its support is more addressed to planning and organizing municipal strategies. Although, Serbia has created interesting and well designed rural development strategies; most of these strategies were formulated by top-down overview. And for the stakeholders getting economical support from government should be by local projects. Nevertheless, other stakeholder working with initiatives reach a financial support still is inadequate due to procedures.

\subsection{Sustainable initiatives through fostering re-connect territorial agro-food and rural tourism}

To this aim, according to suggestions from local stakeholders, farmers and representatives of municipality; they have suggested the establishment of a manager and/or consortium (i.e. an agent that might act for other stakeholders that were not considered in this case study). This manager should organise to the previous stakeholder and initiatives of being part to the existing network. In this case the established network would comprise by Farm Company (i.e. for setting up a strong network).

These factors have been the basis to suggest possible relations involving more stakeholders (Figure 2). Because, would not only are implied with local agrobiodiversity as well rural tourism and organic farming in less proportion. Hence, through this hypothetical case fostering to 'Farm Company - FC', it might to the local producers (Figure 2).

This manager (FC) may involve more stakeholders and necessarily, it should organize and involve with the municipality to create a local retailer in Dimitrovgrad town. A vertical network fits through a possible short supply food chain, may be structured connecting between local producer and consumers (Murdoch; Marsden, 2000). The institutional support is necessary for strengthening this network, thought, and at the moment still is matching regional and local strategies; as well social network may be more encouraged and should change steadily the attitude of farmers. These synergies may more promote local products issues from autochthonous agrobiodiversity, crafts and rural tourism products.

Local products are embedded to the place. Seeing the potential of smallholder making local products and how they are promoted steadily through local events (Regional Fair of Balkan Agrobiodiversity and Rural Heritage). The features meet the conditions to encourage re-connect consumers and food producers/providers, since local products take into account the environmental conditions, artisanal techniques, which are still elaborated (Wiskerke, 2009). Tourism office has started supporting and involving to the young in local activities. It as well should foster to municipality in provide an advice centre for them and local entrepreneurs should remain involving in local jobs (tourism, local livestock breeds, crafts). 


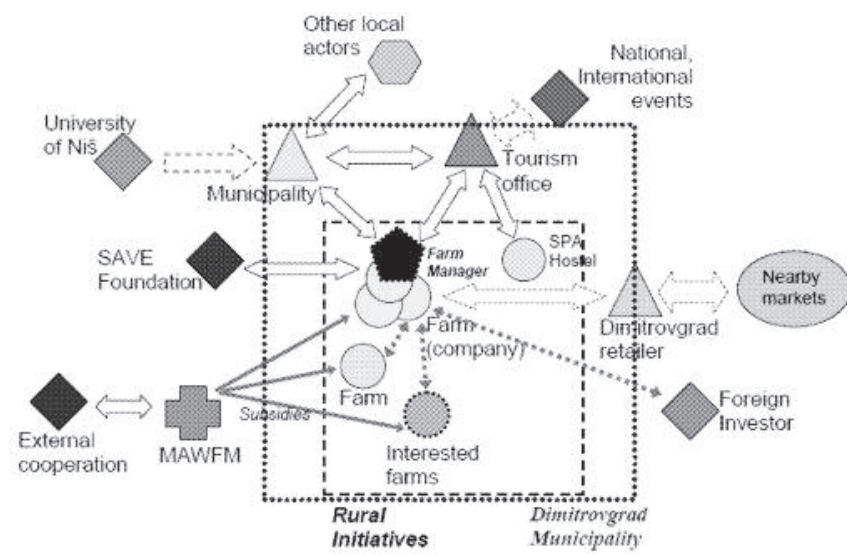

Figure 3. Suggested framework, whether Farm Company become manager for the farmers from marginal villages in Dimitrovgrad (Source: Own Figure)

However, is necessary the active involvement of local agencies, mainly for being sustainable projects and imply more local and external organizations. Particularly promote them through rural tourism activities (e.g. local tourism, agro-tourism, ecotourism), as well as institutional support (Murdoch, 2000; Marsden, 2006). This framework outlines more commitment of local actors and organizations focusing initiatives and rural tourism. Through an integrated tourism, on-farm and non-farm initiatives may be more linked, maintaining the economic and socio-cultural features of the localities take place (Cawley \& Gillmor, 2008; Saxena \& Ilbery, 2010). Nevertheless, here it may run, whether municipality, tourism office and farm manager become a coordination. It shall provide more promotion on rural tourism, rural life, traditional crafts and traditions for the visitors and/or tourists. Furthermore, social network may be strengthened, mainly to the stakeholders encouraging their social networks (Vergunst et al., 2009).

\section{Conclusions}

This paper set out to investigate the efforts made for smallholders and organizations to become sustainable and promote products through initiatives in Dimitrovgrad municipality.

While there is sound strategically to preserve local agrobiodiversity and promote steadily local food products, these appear important issues concerning to development of marginal rural areas in Dimitrovgrad. The cases taken into account are involved through local projects, foreign investors, local organizations and own funds, and also being part of international networks, which provides technical assistance. However, exogenous support may still be necessary to sustain the main manager and should engage to coordinate between local actors, local agencies, intermediate institutions and external agents (horizontal network).

Nevertheless, it should not be focus on this group, and also it should organize the other stakeholders that are pursuing with initiatives or want to start. There are further means of support to keep local livestock through subsidies provided from Agricultural Ministry. Thereby, seen in other villages, there are smallholder interested to access this subvention, hence they necessarily should meet the procedures to reach it.

Horizontal and vertical networking and embeddedness upon initiatives were proposed as being conductive to maximize resource use and achieving the basic purpose to reconnect local food products to nearly markets. Examples of successful horizontal embedded networking were identified, as was vertical networking to attract tourists. Deficiencies in local networking served, however, to inhibit development in more remote areas. Re-valuing local food taking local resources turn around on a likely integrated territorial agrofood. Regarding environmental sustainability, the farms may be strengthened their networks inside of initiatives.

Farmers that live in these areas still manage by organic farming on a small scale and through rural initiatives. The importance of agrobiodiversity should stimulate the government to coordinate and improve rural strategies by promoting better integration between institutional and local stakeholders. In addition, the government should run awareness-making campaigns to convince entrepreneurs that protecting and enhancing agrobiodiversity is feasible and relevant for future viable agricultural production in those areas.

Rural tourism should be advocate both by official bodies as well as by individual farmers. Elderly people retiring and leaving the productive economy altogether, it is evident that for rural areas to retain their economic vitality it is important for alternative income source to be created therein. Promoting an Integrated sustainable rural tourism it will increase possible source of enhanced employment, expansion of high quality handicraft production.

Although, there are adequate rural tourism infrastructure (at the present occupancy rates are relatively low, which majority of transits). Seeing the expansion of established initiatives, and present potential in villages could be the expansion of handicrafts and specialist in high-quality food issue from indigenous livestock. All of which could provide direct employments possibilities for people living in rural areas. Nevertheless, there are main factors can limit the direct benefit, like small size of country, enabling to visitors to stay there. Besides, few of the facilities available in rural areas are below the quality expected by most international tourist, thus restricting their desire to visit them. One of the strategies to improve initiatives may be through development of website. Despite of locating in marginal villages, these tools can help to attract visitors. In addition may provide information to external visitors, seeing now a globalized world. Through this mean should display the products offered by farms as well the local products. Several experiences using these means have been successful promoting local products.

\section{Acknowledgements}

Thankful to TEMPUS Project and IMRD framework programme for financing the fieldwork as well as the 
scholarship granted. Special thanks to Sergej Ivanov, Alexandar Vasov, the farmers and people in Dimitrovgrad Municipality for their collaboration.

\section{References}

Bogdanov, N. (2007): Mala ruralna domaćinstava u srbiji i ruralna nepoljoprivredna ekonomija. UNDP, Srbija (United Nations Development Programme). Beograd, Srbija.

Bogdanov, N., Bozic, D., Yavuz, F., Gul, A., Wibberley, J., Turner, M. (2006): Agro economic policy analysis of the new member states, the candidate stats ant eh countries of the western Balkan. CEEC AGRI POLICY. Institute of Agricultural Economics. Faculty of Agriculture, University of Belgrade. Belgrade, Serbia. 26p.

Brunori, G., Cerruti, R., Medeot, S., Rossi, A. (2008): Looking for alternatives: the construction of the organic beef chain in Mugello, Tuscany. Int. J. Agricultural Resources, Governance and Ecology 7(1/2): 126-143.

Callon, M. (1999): Actor-network theory - the market test. Pp.181195. In: Actor Network Theory and after. Law, J. \& Hassard, J. (Eds.). Blackwell Publishers, Cowley Road, Oxford, UK.

Cawley, M. \& Gillmor, D.A. (2008): Integrated Rural Tourism: concepts and practice. Annals of Tourism Research 35 (2): 316-337.

Djordjevic-Milosevic, S. (2008): Monitoring the Mediterranean strategy for sustainable development (MSSD): Agricultural and rural development in Republic of Serbia. Plan Bleu, Centre d'Activités Régionales. Belgrade, Serbia. 126p.

Köhler-Rollefson, I. (2007): Endogenous versus Globalized: An alternative vision of livestock development for the poor. Discussion paper. League for Pastoral Peoples and Endogenous Livestock Development. Over-Ramstadt, Germany. 20p.

Kucerova, E. (2002): Active social policy as a chance for endogenous rural development. Agricultural Economics 48 (12): $554-558$.

Marczin, O., Đorđević Milošević, S., Ivanov, S. (2007): Smernice za Razvoj održive poljoprivrede na području Stare Planine. Republika Srbija. Regional Environmental Center, Serbia. Swiss Agency for Development and Cooperation, SDC.

Marsden, T., Banks, J., Bristow, G. (2000): Food supply chain approaches: exploring their role in rural development. Sociologia Ruralis 40(4): 424-438.

Marsden, T. (2006): The road towards sustainable rural development: issues of theory, policy and practice in a European Context. Pp. 201-212. In: Cloke, P., Marsden, T. \& Mooney, P.H. (Eds.) Handbook of Rural Studies. SAGE Publications Ltd. London EC 1Y 1SP.

Milone, P. (2009): Agriculture in Transition: A neo-institutional analysis. Royal Van Gorcum. Assen, The Netherlands.

Mühlinghaus, S. \& Wälty, S. (2001): Endogenous development in Swiss mountain communities: Local initiatives in Urnasch and Schamserberg. Mountain Research and Development 21(3): 236-242.

Murdoch, J. (2000): Networks - a new paradigm of rural development? Journal of Rural Studies. 16: 407-419.

O.E.C.D. (1994): Creating rural indicators for shaping territorial policy. Paris, France.
Remmers, G.A. (1996): Hitting a moving target: Endogenous development in marginal European Areas. Gatekeeper Series No. 63. IIED (International Institute for Environmental and Development). Sustainable Agriculture and Rural Livelihoods Programme. London, UK. 17p.

Remmers, G.A. (2006): A European Network for Endogenous Development? Food for reflection and an invitation to build it. Moving Worldviews: Reshaping sciences, policies and practice for endogenous sustainable development

Saxena, G. \& Ilbery, B. (2010): Developing integrated rural tourism: actor practices in the English/Welsh border. Journal of Rural Studies, in press.

S.O.R.S. (2008a): Statistical Yearbook Serbia, 2008. S.O.R.S. (Statistical Office of the Republic of Serbia). Belgrade, Serbia. Viewed 16 August, 2009. Available http://webrzs.stat.gov.rs/ axd//en/god.htm

S.O.R.S. (2008b): Innovation activities in enterprises in the Republic of Serbia, 2004-2006. Communication, S.O.R.S. (Statistical Office of the Republic of Serbia). 2008. Viewed 16 August, 2009. Available <http://webrzs.stat.gov.rs/axd//en/god.htm>

Sonino, R., Kanemasu, Y., Marsden, T. (2008): Sustainability and Rural Development. pp. 29-52. In: Unfolding Webs: The dynamics of regional rural development. J.D. van der Ploeg, T. Marsden (Eds.). Royal Van Gorcum, Assen, The Netherlands.

Subic, J., Vasiljevic, Z., Cvijanovic, D. (2009): Strategic planning in the function of sustainable agricultural and rural development in Republic of Serbia. 1005-1012p. In: $4^{\text {th }}$ Aspects and Visions of Applied Economics and Informatics, March 26-26, 2009, Debrecen, Hungary.

Stojanovic, S. (2008): Use of Farm Animal Genetic Resources in Serbia in Rural Tourism. In: DAGEN-SAVE Conference Kozard, Hungary, 12-14 June, 2008. DAGENE: Regional Partner in the European SAVE Network: International Association for the Conservation of Animal Breeds in the Danubian Region. Topic: Use of rare breeds and plants for genuine food in rural tourism. Viewed: 25 Sept, 2009, Available <http://www.save-foundation.net/ Conferences/Kozard/Stojanovi_Serbia_Kozard.pdf>

Tovey, H., Bruckmeier, K., Mooney, R. (2009): Innovation in rural development and rural sustainable development. pp. 243-266. In: Bruckmeier, K. \& Tovey, H. (Eds.) Rural Sustainable Development in the Knowledge Society. Ashgate Publishing Ltd. Surrey, England.

Van der Ploeg, J.D., Renting, H., Brunori, G., Knickel, K., Mannion, J., Marsden, T., Roest, K.D., Sevilla-Guzmán, E., Ventura, F. (2000): Rural Development: from practices and policies towards theory. Sociologia Ruralis 40(4): 391-408

Vergunst, J., Árnason, A., Macintyre, R. \& Nighitingale, A. (2009): Using Environment resources: networks in food and landscape. Pp. 143-169. In: Árnason, A., Shucksmith, M. \& Vergunst, J. (Eds.). Comparing Rural Development continuity and change in the countryside of Western Europe. Ashgate Publishing Limited. Surrey GU9 PT, England.

Wiskerke, H. (2009): An integrated and territorial perspective on food studies, governance and planning. Slides In: feeding the city. Wageningen University - Rural Sociology Group.

Ying, R. (2003): Case Study Research: Design and Methods, SAGE Publications Inc, California, USA. 